\title{
PENGARUH KINERJA KEUANGAN TERHADAP RETURN SAHAM
}

\section{(STUDI PADA EMITEN SAHAM SYARIAH SEKTOR MANUFAKTUR YANG TERDAFTAR DI INDEKS \\ SAHAM SYARIAH INDONESIA TAHUN 2011-2012)}

\author{
Rizkary Roslianti \\ Mahasiswa Program Studi S1 Ekonomi Islam - Fakultas Ekonomi dan Bisnis - Universitas \\ Airlangga \\ Email: rizkaroslianti@yahoo.com \\ Leo Herlambang \\ Departemen Ekonomi Syariah - Fakultas Ekonomi dan Bisnis - Universitas Airlangga \\ Email: leo.herlambang@gmail.com
}

\begin{abstract}
:
Islamic stocks is one of the most preffered investment type by Muslim investors. In the decision making process, the investors have to considered the financial reports and stock analysis. This study aims to investigate the effect of fundamental factors that represented by Return on Assets, Debt to Equity Ratio and Total Assets Turnover toward stock return.

This study used a quantitative approach using secondary data, they are financial statements and stock return companies listed on Indeks Saham Syariah Indonesia years 2011 2012. This study used a significance level of $5 \%$.

Based on the regression analysis results, it indicates that Return on Assets variable has a very significant effect on the stock return. On the other hand, Debt to Equity Ratio variable and Total Assets Turnover variable do not have significant effect to the stock return. Simultaneously, Return on Assets, Debt to Equity Ratio and Total Assets Turnover have significant effect to stock return.
\end{abstract}

Keywords : Islamic Stocks, Return on Assets, Debt to Equity Ratio, Total Assets Turnover, Stock Return

\section{PENDAHULUAN}

Saham merupakan salah satu bentuk investasi dengan menanamkan modal kepada suatu perusahaan yang mengeluarkan surat kepemilikan saham guna memberikan kesempatan kepada investor untuk ikut menanamkan modal. Modal yang terkumpul atas saham suatu perusahaan yang dibeli oleh masyarakat, nantinya akan digunakan untuk kegiatan operasional yang dilakukan oleh perusahaan tersebut, dimana secara tidak langsung investor juga memiliki andil yang cukup besar sesuai dengan porsi modal yang mereka investasikan kepada perusahaan tersebut dalam kegiatan operasional perusahaan yang bersangkutan.

Saham ketika dikaitkan dengan konsep ekonomi syariah saat ini mulai banyak perusahaan di Indonesia yang mengeluarkan saham syariah. Semakin tahun terlihat bahwa saham syariah makin meningkat. 


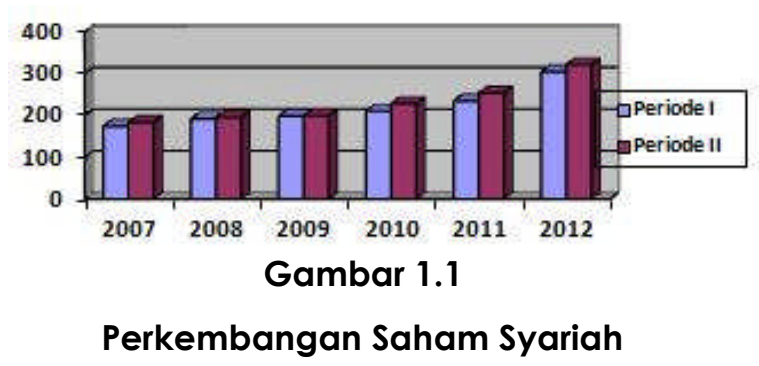

Sumber: www.bapepam.go.id

Bapepam dan LK sejak November 2007 telah mengeluarkan Daftar Efek Syariah (DES) yang berisi daftar saham syariah yang ada di Indonesia. DES diharapkan dapat mempermudah masyarakat untuk mengetahui sahamsaham apa saja yang termasuk saham syariah karena DES adalah satu-satunya rujukan tentang daftar saham syariah di Indonesia. Keberadaan DES tersebut ditindaklanjuti oleh BEl dengan meluncurkan Indeks Saham Syariah Indonesia (ISSI) pada tanggal 12 Mei 2011. Saham konstituen ISSI update per 18 Desember 2013 terdapat 312 emiten yang terdaftar. Beberapa diantaranya yang terdaftar merupakan emiten perusahaan manufaktur.

Banyak faktor yang dapat mempengaruhi pertumbuhan industri manufaktur salah satunya adalah pergerakan ekonomi global yang saat ini masih belum stabil. Salah satu hal yang dapat menjadi kekuatan bagi industri manufaktur untuk tetap bertahan dengan kondisi ekonomi global yang tidak stabil adalah dengan kekuatan kinerja keuangan yang dimiliki perusahaan tersebut. Kinerja keuangan tersebut juga mempengaruhi return saham perusahaan yang terdaftar dalam pasar modal. Tingginya return saham yang akan didapatkan dipengaruhi oleh berbagai macam faktor, salah satunya yaitu faktor fundamental. Faktor fundamental menganalisis berbagai faktor kinerja keuangan suatu perusahaan tertentu dengan menggunakan rasio keuangan perusahaan terkait.

Penelitian sebelumnya juga banyak yang meneliti hal yang hampir sama. Hasil dari penelitian sebelumnya terdapat perbedaan. Berdasarkan pertimbangan akan pemilihan saham yang akan dijadikan suatu investasi bagi para investor dan juga berbagai perbedaan hasil penelitian yang dilakukan sebelumnya, maka perlu adanya analisis yang dilakukan dengan menggunakan faktor fundamental yaitu dengan mempertimbangkan rasio keuangan perusahaan. Penulis terdorong untuk melakukan penelitian dengan judul: "Pengaruh Kinerja Keuangan Terhadap Return Saham (Studi pada Emiten Saham Syariah Sektor Manufaktur yang Terdaftar di Indeks Saham Syariah Indonesia tahun 2011-2012)".

\subsection{Rumusan Masalah}

Berdasarkan latar belakang tersebut, masalah yang akan diteliti dalam penelitian ini adalah :

1. Apakah Return on Assets (ROA) berpengaruh signifikan secara parsial terhadap return saham perusahaan manufaktur yang terdaftar di Indeks Saham Syariah Indonesia (ISSI) tahun 2011-2012 ? 
2. Apakah Debt to Equity Ratio (DER) berpengaruh signifikan secara parsial terhadap return saham perusahaan manufaktur yang terdaftar di Indeks Saham Syariah Indonesia (ISSI) tahun 2011-2012?

3. Apakah Total Asset Turnover (TATO) berpengaruh signifikan secara parsial terhadap return saham perusahaan manufaktur yang terdaftar di Indeks Saham Syariah Indonesia (ISSI) tahun 2011-2012?

4. Apakah Return on Assets (ROA), Debt to Equity Ratio (DER) dan Total Asset Turnover(TATO) berpengaruh signifikan secara simultan terhadap return saham perusahaan manufaktur yang terdaftar di Indeks Saham Syariah Indonesia (ISSI) tahun 2011-2012?

\subsection{Tujuan Penelitian}

Sesuai dengan rumusan masalah yang akan diteliti dalam penelitian ini, maka tujuan yang ingin dicapai adalah sebagai berikut :

1. Untuk mengetahui pengaruh secara parsial Return on Assets (ROA) terhadap return saham perusahaan manufaktur yang terdaftar di Indeks Saham Syariah Indonesia (ISSI) tahun 2011-2012.

2. Untuk mengetahui pengaruh secara parsial Debt to Equity Ratio (DER) terhadap return saham perusahaan manufaktur yang terdaftar di Indeks Saham Syariah Indonesia (ISSI) tahun 2011-2012.

3. Untuk mengetahui pengaruh secara parsial Total Asset Turnover (TATO) terhadap return saham perusahaan manufaktur yang terdaftar di Indeks Saham Syariah Indonesia (ISSI) tahun 2011-2012.

4. Untuk mengetahui pengaruh secara simultan Return on Assets (ROA), Debt to Equity Ratio (DER) dan Total Asset Turnover (TATO) simultan terhadap return saham perusahaan manufaktur yang terdaftar di Indeks Saham Syariah Indonesia (ISSI) tahun 2011-2012.

\section{TINJAUAN PUSTAKA}

\section{Saham Syariah}

Saham syariah secaran umum hampir sama dengan saham biasa yang sudah ada di masyarakat. Yang membedakan saham biasa dengan saham syariah adalah segala sesuatu yang dilakukan seperti kegiatan usaha dan tujuan dalam saham syariah harus berdasarkan aturan dan kaidah secara Islam yang sudah ditetapkan dan dijelaskan dalam Al-Qur'an dan Hadist.

Saham syariah menurut Heykal (2012: 44) adalah kegiatan investasi berupa penyertaan modal yang dilakukan ke dalam perusahaanperusahaan yang dalam kegiataannya tidak melanggar prinsip syariah.

\section{Return Saham}

Pengembalian (return) adalah total keuntungan atau kerugian yang dialami pemilik modal/investor dalam suatu periode tertentu yang dihitung dengan membagi perubahan nilai aktiva ditambah pembagian hasil dalam 
periode tersebut dengan nilai investasi awal periode (Sundjaya dan Barlian. 2002: 47). Tandelilin (2010) menjelaskan bahwa sumber-sumber return investasi terdiri dari dua kompoen utama yaitu:

1. Yield yaitu komponen return yang mencerminkan aliran kas atau pendapatan yang diperoleh secara periodik dari suatu investasi.

2. Capital gain (loss) yaitu komponen kedua dari return yang merupakan kenaikan (penurunan) harga suatu surat berharga (bisa saham maupun surat hutang jangka panjang) yang bisa memberikan keuntungan (kerugian) bagi investor.

Brigham dan Houston (1998: 316) menjelaskan bahwa return saham dapat dihitung dengan menggunakan persamaan:

$$
R_{t}=\frac{P_{t}-P_{0}}{P_{0}}
$$

Keterangan:

$R_{t}=$ Return actual saham i periode $\dagger$

$P_{t}=$ Harga saham i periode $\dagger$

$P_{0}=$ Harga saham $\mathrm{i}$ periode $\mathrm{t}-1$

\section{Return on Assets (ROA)}

Return on Assets (ROA) menunjukkan kemampuan perusahaan dengan menggunakan seluruh aktiva yang dimiliki untuk menghasilkan laba setelah pajak. Rasio ini dapat digunakan untuk mengukur profitabilitas manajemen perusahaan dalam mengelola seluruh aktiva perusahaan (Sudana, 2011: 22). ROA yang tinggi menunjukkan bahwa kinerja yang dimiliki perusahaan dinilai baik. Semakin tinggi Return on Assets, maka semakin besar pula kemampuan perusahaan untuk menghasilkan laba bersih yang tersedia bagi pemilik modal. Laba bersih yang semakin tinggi yang dapat dicapai oleh perusahaan, maka akan meningkatkan nilai perusahaan. Laba tinggi yang dapat dicapai oleh perusahaan akan meningkatkan minat para investor untuk menanamkan saham pada perusahaan tersebut. Hal ini juga akan berpengaruh pada peningkatan harga saham perusahaan tersebut. Harga saham yang naik akan berpengaruh pada kenaikan return saham. Dengan kata lain, ROA memiliki pengaruh terhadap return saham.

$$
R O A=\frac{\text { Laba bersih setelah pajak }}{\text { Total aset }}
$$

\section{Debt to Equity Ratio (DER)}

Debt to Equity Ratio (DER) menunjukkan perbandingan antara total hutang dengan total ekuitas yang dimiliki perusahaan untuk mendanai usaha yang dimiliki perusahaan (Husnan dan Pudjiastuti, 2012: 72). Semakin besar DER suatu perusahaan menandakan bahwa perusahaan tersebut menggunakan hutang yang besar sebagai sumber pendanaan perusahaan, sehingga menyebabkan risiko perusahaan semakin tinggi. Hal ini menyebabkan tingkat permintaan saham akan perusahaan tersebut semakin menurun karena investor cenderung menghindari perusahaan yang memiliki risiko tinggi. Tingkat pengembalian yang akan diterima oleh 
investor juga sedikit. DER suatu perusahaan tentu juga berdampak pada harga saham, dimana semakin besar DER, maka akan menyebabkan harga saham semakin menurun karena risiko yang dimiliki juga samakin meningkat. Penurunan harga saham akan mempengaruhi return saham. Dengan kata lain, DER memiliki pengaruh terhadap return saham.

Debt to Equity Ratio $(D E R)=\frac{\text { Total Hutang }}{\text { Total Ekuitas }}$

\section{Total Assets Turnover (TATO)}

Total Assets Turnover (TATO) merupakan salah satu rasio yang menunjukkan tingkat efektivitas yang dilakukan oleh perusahaan dalam menggunakan aset yang dimilikinya. Perusahaan lebih menyukai mendukung tingkat penjualan yang tinggi dengan jumlah aktiva yang relatif rendah sehingga artinya perusahaan dapat memanfaatkan aktiva yang telah diinvestasikan secara efektif (Madura. 2009:359). TATO ini membandingkan antara penjualan dengan total aset yang dimiliki oleh perusahaan tersebut. Semakin tinggi rasio TATO sebuah perusahaan maka semakin baik (Harahap, 2004:309).

$$
\text { TATO }=\frac{\text { Penjualan }}{\text { Total aset }}
$$

\section{Hipotesis}

Berdasarkan rumusan masalah dan tujuan penelitian ini, hipotesis yang digunakan dalam penelitian ini adalah:

$H_{1}$ : Return on Assets (ROA) berpengaruh signifikan terhadap return saham perusahaan manufaktur yang terdaftar dalam Indeks Saham Syariah Indonesia (ISSI) tahun 20112012.

$\mathrm{H}_{2}$ : Debt Equity Ratio (DER) berpengaruh signifikan terhadap return saham perusahaan manufaktur yang terdaftar dalam Indeks Saham Syariah Indonesia (ISSI) tahun 20112012.

\section{$\mathrm{H}_{3}$ :Total Asset Turnover (TATO) berpengaruh signifikanterhadap return saham perusahaan manufaktur yang terdaftar dalam Indeks Saham Syariah Indonesia (ISSI) tahun 2011-2012.}

$H_{4}$ :Return on Assets (ROA), Debt Equity Ratio (DER) dan Total Asset Turnover (TATO) berpengaruh signifikan terhadap return saham perusahaan manufaktur yang terdaftar dalam Indeks Saham Syariah Indonesia (ISSI) tahun 20112012. 


\section{Model Analisis}

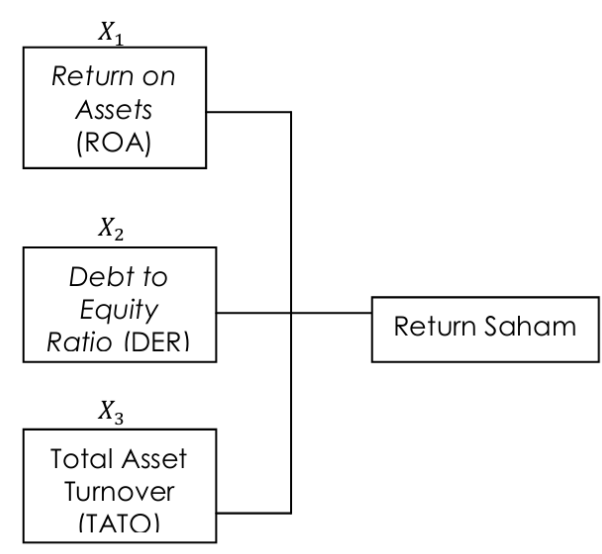

Gambar 2.1

Model Analisis

Sumber: Madura: 2009, diolah penulis.

\section{METODE PENELITIAN}

Penelitian ini menggunakan pendekatan kuantitatif dengan menggunakan data sekunder yang meliputi dua variabel yang akan diteliti dalam penelitian ini. Kedua variabel tersebut adalah variabel dependen yang diwakili oleh return saham perusahaan manufaktur yang terdaftar di Indeks Saham Syariah Indonesia (ISSI) tahun 2011 2012 serta variabel independen yang diwakili oleh Return on Assets, Debt to Equity Ratio dan Total Assets Turnover.

Pengujian hipotesis pada penelitian ini dilakukan dengan uji † untuk menguji apakan variabel independen yang digunakan dalam penelitian ini berpengaruh signifikan secara parsial terhadap return saham dan uji $F$ untuk menguji apakah variabel independen yang digunakan dalam penelitian ini berpengaruh signifikan secara simultan terhadap return saham. Penelitian ini menggunakan tingkat signifikansi sebesar
$5 \%$.

Penelitian ini menggunakan teknik analisis regresi linear berganda (Multiple Linear Regression Analysis) dengan memanfaatkan data yang didapatkan dari penggabungan antara data cross section (beberapa emiten tertentu) dengan data time series (lingkup waktu selama beberapa tahun tertentu). Analisis regresi linear berganda ini bertujuan untuk mengetahui hubungan antara variabel dependen dan variabel independen. Berikut adalah model regresi penelitian yang digunakan :

$$
Y=a+b_{1} X_{1}+b_{2} X_{2}+b_{3} X_{3}+e
$$

\section{Dimana :}

$$
\begin{array}{ll}
Y & =\text { return saham } \\
X_{1} & =\text { Return on Assets (ROA) } \\
X_{2} & =\text { Debt to Equity Ratio (DER) } \\
X_{3} & =\text { Total Asset Turnover (TATO) } \\
b_{1}, b_{2}, b_{3} & =\text { Koefisien regresi masing-masing } \\
& \text { variabel independen } \\
e & =\text { Faktor pengganggu di luar } \\
& \text { model penelitian }
\end{array}
$$

Dari model analisa regresi linear yang digunakan, terdapat beberapa asumsi klasik yang dapat digunakan untuk mengestimasi hasil agar tidak ada penyimpangan sehingga dapat memberikan informasi yang sesuai dengan data yang tersedia. Asumsi klasik tersebut adalah uji multikolinearitas, uji heteroskedastisitas, uji autokorelasi, uji normalitas.

\section{Populasi}

Menurut Sugiyono (2011: 80) populasi adalah wilayah generalisasi yang terdiri atas obyek/ subyek yang mempunyai kualitas dan karakteristik 
tertentu yang ditetapkan oleh peneliti untuk dipelajari dan kemudian ditarik kesimpulannya. Populasi dalam penelitian ini menggunakan kriteria populasi sebagai berikut:

a. Termasuk dalam Indeks Saham Syariah Indonesia (ISSI) pada tahun 2011-2012.

b. Tidak keluar masuk selama tahun 20112012 dalam Indeks Saham Syariah Indonesia (ISSI).

c. Termasuk perusahaan manufaktur.

d. Mempunyai data ringkasan keuangan pada tahun 2011-2012.

Sampel adalah beberapa bagian dari banyaknya populasi yang dipilih berdasarkan karakteristik yang diinginkan untuk diteliti dalam suatu penelitian. Seluruh sampel yang digunakan adalah anggota populasi yang diteliti. Penelitian ini menggunakan populasi dengan kriteria yang telah dijelaskan diatas yaitu sebanyak 68 perusahaan manufaktur selama 2 tahun.

\section{Definisi Operasional}

Tabel 3.1.

\section{Devinisi Operasional Variabel}

\begin{tabular}{|c|c|c|}
\hline No & Variabel & Rumus \\
\hline 1. & $\begin{array}{l}\text { Return on } \\
\text { Assets } \\
\text { (ROA) }\end{array}$ & ROA $=\frac{\text { Laba bersih setelah pajak }}{\text { Total aset }}$ \\
\hline 2. & $\begin{array}{l}\text { Debt to } \\
\text { Equity } \\
\text { Ratio } \\
\text { (DER) }\end{array}$ & $\mathrm{DER}=\frac{\text { Total Hutang }}{\text { Total Ekuitas }}$ \\
\hline 3. & $\begin{array}{l}\text { Total } \\
\text { Assets } \\
\text { Turnover } \\
\text { (TATO) }\end{array}$ & TATO $=\frac{\text { Penjualan }}{\text { Total aset }}$ \\
\hline 4. & $\begin{array}{l}\text { Return } \\
\text { Saham }\end{array}$ & $R_{\tau}=\frac{P_{\tau}-P_{0}}{P_{0}}$ \\
\hline
\end{tabular}

Sumber: Madura: 2009, Brigham dan Houston: 1998, diolah penulis.

\section{HASIL DAN PEMBAHASAN}

Uji Multikolinearitas

Tabel 4.1.

Hasil Uji Multikolinearitas

\begin{tabular}{|c|c|c|c|}
\hline \multirow{2}{*}{ Variabel } & \multicolumn{2}{|c|}{ Collinearity Statistics } & \multirow{2}{*}{ Kesimpulan } \\
\hline & Tolerance & VIF & \\
\hline ROA & 0,893 & 1,119 & $\begin{array}{c}\text { Bebas } \\
\text { multikolinearitas }\end{array}$ \\
\hline DER & 0,896 & 1,116 & $\begin{array}{l}\text { multikolinearitas } \\
\text { Bebas }\end{array}$ \\
\hline TATO & 0,866 & 1,154 & multikolinearitas \\
\hline
\end{tabular}

Sumber : Hasil olah data

Berdasarkan hasil tabel diatas, diketahui bahwa nilai VIF untuk masingmasing variabel kurang dari 10 dan nilai tolerance-nya lebih dari 0,10. Hal ini menunjukkan bahwa tidak terjadi gejala multikolinearitas atau dengan kata lain asumsi nonmultikolinearitas telah terpenuhi.

\section{Uji Heteroskedastisitas}

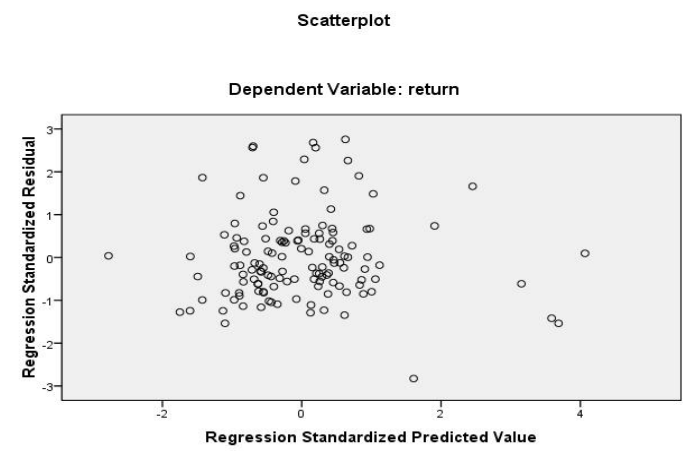

Sumber : Hasil olah data

\section{Gambar 4.1.}

\section{Hasil Uji Heteroskedastisitas berdasarkan Hasil Scatterplot}

Berdasarkan gambar diatas dapat dikatakan bahwa titik-titik menyebar secara acak dan tidak membentuk suatu pola tertentu. Titik-titik data tersebut menyebar diatas dan dibawah atau sekitar angka 0 sehingga dapat 
disimpulkan bahwa dalam data tersebut tidak terjadi heteroskedastisitas.

\section{Uji Autokorelasi}

Tabel 4.2.

\section{Hasil Uji Autokorelasi}

\begin{tabular}{|c|c|c|c|c|c|}
\hline Model & $\mathrm{R}$ & R Square & $\begin{array}{c}\text { Adjusted R } \\
\text { Square }\end{array}$ & $\begin{array}{c}\text { Std. Error of the } \\
\text { Estimate }\end{array}$ & Durbin-Watson \\
\hline 1 & $.336^{s}$ & .113 & .092 & .358596232 & 2.079 \\
\hline
\end{tabular}

Sumber : Hasil olah data

Dari hasil pengujian yang dilakukan dengan data-data yang telah ditentukan, diketahui bahwa nilai DW sebesar 2.079 dengan $k$ sebanyak 4 (jumlah variabel) dan $n$ sebanyak 132 (jumlah data) maka nilai $\mathrm{dU}$ dan $\mathrm{dL}$ adalah 1.762 dan 1.670. Maka nilai autokorelasi diantara $1.762<2.079<2.238$ jadi dapat disimpulkan bahwa tidak terjadi autokorelasi.

\section{Uji Normalitas}

Normal P-P Plot of Regression Standardized Residual

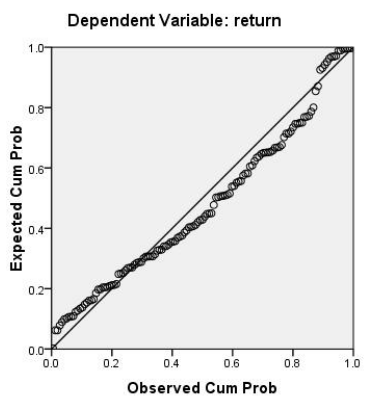

Sumber : Hasil olah data

Gambar 4.2.

Hasil Uji Normalitas berdasarkan Hasil Probability Plot

Hasil output SPSS 16.0 diatas menunjukkan bahwa data menyebar disekitar garis diagonal dan mengikuti arah garis diagonal. Kesimpulan dari hasil Normal probability Plot diatas adalah model regresi memenuhi asumsi normalitas.

\section{Analisis Regresi Linear Berganda}

Tabel 4.3.

\section{Hasil Analisis Regresi Linear Berganda}

\begin{tabular}{|ll|r|r|}
\hline \multirow{2}{*}{ Model } & \multicolumn{2}{|c|}{$\begin{array}{c}\text { Unstandardized } \\
\text { Coefficients }\end{array}$} \\
\cline { 2 - 3 } & \multicolumn{2}{|c|}{ B } & \multicolumn{1}{|c|}{ Std. Error } \\
\hline 1 (Constant) & 0.004 & 0.086 \\
\multicolumn{1}{|c|}{ ROA } & 0.013 & 0.004 \\
\multicolumn{2}{|c|}{ DER } & 0.014 & 0.069 \\
\multicolumn{2}{|l|}{ TATO } & 0.043 & 0.057 \\
\hline
\end{tabular}

Sumber : Hasil olah data

Berdasarkan hasil pengujian analisis regresi linear berganda pada tabel 4.3. diatas, maka didapatkan kesimpulan sebagai berikut:

$$
Y=0.004+0.013 X_{1}+0.014 X_{2}+0.043 X_{3}
$$

Keterangan:

$Y$ : Return Saham

$X_{1}: R O A$

$X_{2}$ : DER

$X_{3}:$ TATO

Uji F

Tabel 4.4.

Hasil Uji F

\begin{tabular}{|c|c|c|c|c|c|c|}
\hline \multicolumn{2}{|c|}{ Model } & $\begin{array}{l}\text { Sum of } \\
\text { Squares }\end{array}$ & df & Mean Square & $\mathrm{F}$ & Sig. \\
\hline \multirow[t]{3}{*}{1} & Regression & 2.112 & 3 & 0.704 & 5.476 & $0.001^{\mathrm{s}}$ \\
\hline & Residual & 16.588 & 129 & 0.129 & & \\
\hline & Total & 18.701 & 132 & & & \\
\hline
\end{tabular}

b. Dependent Variable: retum

Sumber : Hasil olah data

Tingkat signifikan $\mathrm{F}$ hitung lebih kecil jika dibandingkan dengan tingkat signifikan yang telah ditentukan yaitu 0.05 , 
maka dapat disimpulkan bahwa variable ROA, DER dan TATO berpengaruh signifikan terhadap return saham.

\section{Uji $\uparrow$}

Tabel 4.5.

Hasil Uji $†$

\begin{tabular}{|c|c|c|c|c|c|c|}
\hline \multirow{2}{*}{\multicolumn{2}{|c|}{ Model }} & \multicolumn{2}{|c|}{$\begin{array}{l}\text { Unstandardized } \\
\text { Coefficients }\end{array}$} & \multirow{2}{*}{\begin{tabular}{|l|}
$\begin{array}{c}\text { Standardized } \\
\text { Coefficients }\end{array}$ \\
Beta \\
\end{tabular}} & \multirow[b]{2}{*}{$t$} & \multirow[b]{2}{*}{ Sig. } \\
\hline & & B & Std. Error & & & \\
\hline 1 & (Constant) & 0.004 & 0.086 & & 0.049 & 0.961 \\
\hline & ROA & 0.013 & 0.004 & 0.315 & 3.587 & 0.000 \\
\hline & DER & 0.014 & 0.069 & 0.018 & 0.206 & 0.837 \\
\hline & TATO & 0.043 & 0.057 & 0.068 & 0.761 & 0.448 \\
\hline
\end{tabular}

a. Variabel Return on Asset (ROA) memiliki t hitung sebesar 3.587 dengan signifikan sebesar 0.000. Sedangkan $\dagger$ tabel dengan tingkat signifikan sebesar 0,05 adalah 1.657, maka t hitung $>$ † tabel (3.587 > 1.657) dan nilai signifikan lebih kecil daripada 0,05. Dapat disimpulkan bahwa ROA berpengaruh signifikan secara parsial terhadap return saham.

b. Variabel Debt to Equity Ratio (DER) memiliki † hitung sebesar 0.206 dengan signifikan sebesar 0.837. Sedangkan $\dagger$ tabel dengan tingkat signifikan sebesar 0,05 adalah 1.657, maka $\dagger$ hitung $<\dagger$ tabel $(0.206<1.657)$ dan nilai signifikan lebih besar daripada 0,05. Dapat disimpulkan bahwa DER berpengaruh tidak signifikan secara parsial terhadap return saham.

c. Variabel Total Asset Turnover (TATO) memiliki † hitung sebesar 0.761 dengan signifikan sebesar 0.448. Sedangkan $\dagger$ tabel dengan tingkat signifikan sebesar 0,05 adalah 1.657, maka $\dagger$ hitung $<\dagger$ tabel $(0.761<1.657)$ dan nilai signifikan lebih besar daripada 0,05. Dapat disimpulkan bahwa TATO berpengaruh tidak signifikan secara parsial terhadap return saham.

\section{Pembahasan}

a. Pengaruh ROA terhadap return saham Hasil tersebut menunjukkan bahwa ROA signifikan terhadap return saham sehingga mempengaruhi return saham. rasio ROA yang tinggi maka perusahaan tersebut semakin efisien dalam memanfaatkan aktiva yang dimiliki untuk menghasilkan laba bersih (Madura: 2009: 362). Para investor lebih menyukai perusahaan dengan tingkat laba yang tinggi karena beranggapan bahwa tingkat pengembalian yang akan didapat ikut meningkat. Seperti yang telah dijelaskan dalam Al-Qur'an surat An Najm 39 :

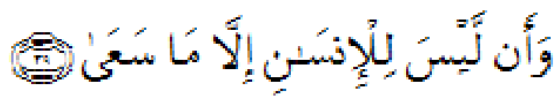

Wa"an laysa lil"innsāni illā mā sa"ā.

Artinya: "Dan bahwasanya seorang manusia tiada memperoleh selain apa yang telah diusahakannya. (Departemen Agama Rl, 2013: 874).

Ayat diatas menjelaskan bahwa manusia harus berusaha dan bekerja keras dalam menggapai apa yang diinginkannya. Dalam hal ini adalah perusahaan harus berusaha untuk menggunakan aset ayng dimiliki secara efisien untuk mendapatkan laba yang diinginkan. Hasil penelitian 
ini sesuai dengan hasil penelitian sebelumnya yang dilakukan oleh Sholeh (2012) dan Cahyadithama (2012) yang menyimpulkan bahwa ROA berpengaruh signifikan terhadap return saham.

b. Pengaruh DER terhadap return saham Hasil tersebut menunjukkan bahwa DER berpengaruh tidak signifikan terhadap return saham. DER berpengaruh tidak signifikan terhadap return saham karena terdapat banyak hal yang mempengaruhi return saham selain DER. Hasil penelitian ini sesuai dengan hasil penelitian sebelumnya yang dilakukan oleh Fahman (2013) dan Budialim (2013) yang menyimpulkan bahwa DER berpengaruh tidak signifikan terhadap return saham.

c. Pengaruh TATO terhadap return saham Hasil tersebut menyimpulkan bahwa TATO berpengaruh tidak signifikan terhadap return saham. Salah satu alasan yang dapat menyebabkan rasio TATO tidak signifikan adalah beberapa investor melihat bahwa aset yang baru dianggap lebih efisien dibandingkan dengan aset lama karena adanya pengaruh teknologi yang semakin canggih. TATO yang tinggi menandakan bahwa perusahaan tersebut sangat efektif dalam menggunakan aset yang dimiliki. Islam menganjurkan untuk efisien dalam segala kegiatan yang dilakukan sehingga menghasilkan hasil yang optimal. Seperti yang dijelaskan dalam Al-Qur'an surat Al Mulk 2 :

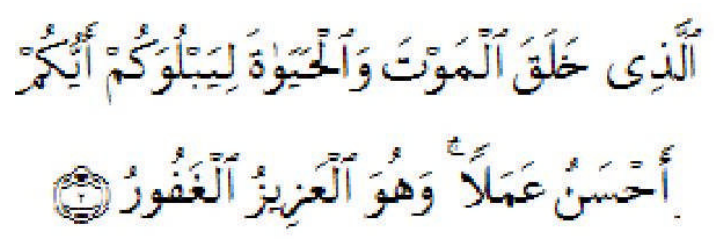

allażī khalaqa almawta wālhayāta liyabluwakum "ayyukum ahsanu 'amalan wahuwa al'azīzu algafūru.

Artinya: "Yang menjadikan mati dan hidup, supaya dia menguji kamu, siapa di antara kamu yang lebih baik amalnya. dan dia Maha Perkasa lagi Maha Pengampun" (Departemen Agama Rl, 2013: 955).

Ayat diatas menjelaskan bahwa kita harus berfikir dan menemukan cara untuk menggunakan apa yang telah kita miliki secara efisien sehingga mendapatkan hasil yang optimal (lebih baik amalnya). Optimal dari suatu perusahaan yaitu terwujudnya efisiensi dan efektifitas yang dilakukan perusahaan tersebut. Hasil penelitian ini sesuai dengan hasil penelitian yang dilakukan oleh Thrisye dan Simu (2013) yang menyatakan bahwa TATO berpengaruh tidak signifikan terhadap harga saham.

d. Pengaruh Return on Assets (ROA), Debt to Equity Ratio (DER) dan Total Assets Turnover (TATO) terhadap Return Saham Secara Simultan Variabel Return on Assets (ROA), Debt to Equity Ratio (DER) dan Total Assets Turnover (TATO) menunjukkan angka signifikan sebesar 0.001 terhadap return saham. Hal ini menunjukkan bahwa ROA, DER dan TATO mempunyai pengaruh signifikan 
terhadap return saham secara bersama-sama atau simultan. Terdapat banyak faktor yang mempengaruhi perubahan return saham. Beberapa diantara faktor-faktor tersebut adalah Return on Assets (ROA), Debt to Equity Ratio (DER) dan Total Assets Turnover (TATO). Pengaruh Return on Asset (ROA), Debt to Equity Ratio (DER) dan Total Assets Turnover (TATO) terhadap return saham dapat dijelaskan sebesar $11.3 \%$ sedangkan sisanya sebesar $88.7 \%$ dijelaskan oleh variabel lain diluar ketiga variabel independen tersebut.

\section{SIMPULAN}

Berdasarkan hasil penelitian dan pembahasan yang telah dilakukan mengenai hubungan antara variabel ROA, DER dan TATO terhadap return saham, maka simpulan yang dapat diambil adalah:

1. Variabel Return on Assets (ROA) berpengaruh signifikan secara parsial terhadap return saham perusahaan manufaktur yang terdaftar di Indeks Saham Syariah Indonesia (ISSI) tahun 2011-2012. Hal ini ditunjukkan dengan tingkat signifikansi sebesar 0.000 yang menandakan bahwa tingkat signifikansi tersebut lebih kecil dari level of signifikan yang digunakan sebesar 0.05.

2. Variabel Debt to Equity Ratio (DER) berpengaruh tidak signifikan terhadap return saham perusahaan manufaktur yang terdaftar Indeks Saham Syariah Indonesia (ISSI) tahun 2011-2012. Hal ini ditunjukkan dengan tingkat signifikansi sebesar 0.837 yang menandakan bahwa tingkat signifikansi tersebut lebih besar dari level of signifikan yang digunakan sebesar 0.05 .

3. Variabel Total Asset Turnover (TATO) berpengaruh tidak signifikan secara parsial terhadap return saham perusahaan manufaktur yang terdaftar di Indeks Saham Syariah Indonesia (ISSI) tahun 2011-2012. Hal ini ditunjukkan dengan tingkat signifikansi sebesar 0.448 yang menandakan bahwa tingkat signifikansi tersebut lebih besar dari level of signifikansi yang digunakan sebesar 0.05 .

4. Variabel ROA, DER dan TATO berpengaruh signifikan secara simultan terhadap return saham perusahaan manufaktur yang terdaftar di Indeks Saham Syariah Indonesia (ISSI) tahun 2011-2012. Hal ini ditunjukkan dengan tingkat signifikansi sebesar 0.001 yang menandakan bahwa tingkat signifikansi tersebut lebih besar dari level of signifikansi yang digunakan sebesar 0.05 .

\section{DAFTAR PUSTAKA}

Budialim, Giovanni. 2013. "Pengaruh Kinerja Kevangan dan Risiko Terhadap Return Saham Perusahaan Sektor Consumer Goods di Bursa Efek Indonesia Periode 2007-2011".

Calyptra: Jurnal IImiah Mahasiswa. Vol 2 No 1. Universitas Surabaya.

Brigham, Eugene F. dan Joel F. Houston. 1998. Fundamentals of Financials 
Management. Eight Edition.

Florida: Harcourt Inc.

Cahyadithama, Kurnifan. 2012. Pengaruh

CR, DER, ROA, ROE dan EPS Terhadap Return Saham Pada Perusahaan Food and Beverage yang Terdaftar di Bursa Efek Indonesia Thun 2006-2010. Skripsi Universitas Airlangga

Departemen Agama RI. 2013. Al-Qur'an dan Tafsirnya. Jakarta: CV Atlas

Fahman, Diaz Ferdy Febiano. 2013. Analisis Pengaruh PER, PBV dan DER Terhadap Return Saham Perusahaan Industri Otomotif.. Skripsi Universitas Airlangga

Harahap, Sofyan Syafri. 2004. Analisis Kritis atas Laporan Kevangan. Edisi Pertama Cet.4. Jakarta: PT Grafindo Persada.

Heykal, Mohamad. 2012. Tuntunan dan Aplikasi Investasi Syariah. Jakarta: PT Elex Media Komputindo

Husnan, Suad dan Enny Pudjiastuti. 2012. Dasar-Dasar Manajemen Keuangan. Yogyakarta: UPP STIM YKPN.

Madura, Jeff. 2009. Pengantar Bisnis. Edisi Keempat. Buku 2. Jakarta: Salemba Empat.

Sholeh, Ilham. 2012. Pengaruh Rasio Likuiditas, Return on Investment, Solvabilitas dan Pemanfaatan Aktiva Terhadap Return Saham (Studi Pada Perusahaan Transportasi yang Terdaftar di BEI). Skripsi Universitas Airlangga Sudana, I Made. 2011. Manajemen
Keuangan Perusahaan Teori

\& Praktik. Jakarta: Penerbit

Erlangga.

Sugiyono. 2011. Statistika untuk Penelitian. Bandung: Alfabeta.

Sundjaja, Ridwan S. dan Inge Barlian. 2002. Manajemen Keuangan Dua. Edisi Ketiga. Jakarta: Prenhallindo.

Tandelilin, Eduardus. 2010. Portofolio dan Investasi. Yogyakarta: Kanisius (Anggota IKAPI)

Thrisye, Risca Yuliana dan Nicodemus Simu. 2013. "Analisis Pengaruh Rasio Kevangan Terhadap Return Saham BUMN Sektor Pertambangan Periode 20072010". Jurnal Ilmiah Akuntansi dan Bisnis. Vil. 8 No. 2. Hal 75-81. Perbanas Institute Jakarta.

http://www.bapepam.go.id/syariah/statist ik/pdf/2013/Statistik_Saham_Maret. $\mathrm{P}$ df diunduh pada tanggal 29 April 2013 pukul 06.11 WIB. 